\title{
特別賞
}

\section{ITL-002 心の文化的多様性：その起源を考える}

\author{
講演者：北山忍 (University of Michigan) \\ 司会者：山岸 俊男 (東京大学)
}

洋の東西の文化, 特に西欧・北米の文化と東アジアの文化を較べると, 認知・感情・動機づけといっ た様々な心理機能にかなりの差異が認められる。総じて, 現代欧米人と較べて現代アジア人は, ょり協 調的（あるいは，非独立的）, かつ包括的（あるいは, 非分析的）である。しかし，ここに見られる文化 間の心理的差異の起源は明らかではない。本講演では, 現代人の心性見られる洋の東西の差異は, 過去 一万年ほどの間に, 地域的生態環境とそこから派生する生業形態（特に牧畜や稲作・麦作などの農耕） に適応する形で生じてきたという可能性を検討する。この適応過程においては, 特定の遺伝子多型が選 択的に母集団に取り込まれ, それらが文化環境の再生産に寄与したと考えられる。生態条件に裏付けら れた, 遺伝子と文化の共進化の過程を明らかにし, 人の心性を解明するためには, 文化人類学・社会学 など社会科学のみでなく生物学・脳科学・遺伝学などを取り込んだ総合的アプローチが不可欠であると 結論する。 